\title{
HBQ1 Gene
}

National Cancer Institute

\section{Source}

National Cancer Institute. HBQ1 Gene. NCI Thesaurus. Code C84969.

This gene may play a role in the transport of oxygen to embryonic tissues. 